tion more or less closely, one feels that on the whole the comparison is fallacious because the natural object has a structure and function depending on certain peculiarities of its own such as rigidity, tensile strength or elasticity, rendering its fine structure (which is 'representational' of a certain architecture and function) fundamentally unlike the work of art which, being 'non-representational', is a pattern or texture representing no structure and function. To me it seems that the comparison is superficial and meaningless (although undoubtedly intriguing), that no conclusion can be based on it, and that it has nothing to do with the "intellectual climate" of our century. I feel that it is allied to the view so often presented to us by art critics that modern artists of certain types reveal to us 'fundamental natural forms' which underlie the real natural shapes which we see. A biologist who has studied plant and animal forms in great detail over many years may well agree that Nature has 'fundamental forms' ; but he knows more or less clearly what these forms are, and is less likely to agree that modern art reveals them. For example, when Henry Moore carves something intermediate between a human figure and a pelvic girdle, I believe that he is making a plain mixture of superficial natural forms and not revealing anything fundamental : this is merely an interpretation, not a criticism. Similarly, I believe that the similarities in the book under review, in so far as they exist at all, are accidental, and reveal nothing fundamental.

This conclusion has no element of antipathy to the works of art in question, many of which I find fascinating or even beautiful in themselves, just as the photomicrographs are fascinating in themselves. But to me they are two independent series. I think that some of the earlier books dealing with form in art and Nature may have approached the truth more closely than this one, though nobody has yet solved the problem.

T. A. Stephenson

\section{SCIENCE IN PROGRESS}

Science in Progress, Eleventh Series

By Armand J. Eardley, Richard J. Russell, J. Tuzo Wilson, Serge A. Korff, C. M. Jansky, Jr., Gerald S. Hawkins, Alfred C. Redfield, B. F. Skinner, Roger J. Williams, E. Cuyler Hammond, J. W. Beard, John Turkevich and A. C. Zettlemoyer. Edited by Hugh Taylor. (The Society of the Sigma $\mathrm{Xi}$ devoted to the Encouragement of Research in Science. National Lectureships 1957 and 1958.) Pp. xii +379. (New Haven, Conn.: Yale University Press; London: Oxford University Press, 1960.) 60s. net.

7 HIS book will appeal to professing amateurs and to amateur-professionals-to those who, as a cultural exercise, are interested in science and what is happoning in various fields ; and to those scientists who are interested in developments outside their own specialities. Since it consists of essays which are surveys and re-appraisals, it will not tell those working in the selected subjects much that they did not already know.

A Greek scholar (say) would find the three contributions on the earth-sciences (Eardley's "The Cause of Mountain Building"; Russell's "Instab- ility of Sea-Level" ; and Tuzo Wilson's "Continental Growth") intelligible and informative. A professor of theology, bracing himself for the disputations on "steady state", would be well briefed on technıques of radio astronomy by reading Gerald S. Hawkins, with a side-interest in "Origins of Cosmic Radiation" (Korff), but he might feel that he was getting more insight into C. M. Jansky, jun., than into his brother Karl and "The Beginnings of Radio Astronomy" about which he was supposed to be writing. The student of geophysics would feel less rewarded, since the work reflects only the thoughts and activities aroused by the International Geophysical Year and little, if any, of the findings.

On the other hand, he, or any exact scientist, would surely find Williams's "Chemical Anthropology" engrossing and challenging. Here is the proposal for the "marriage of chemistry and anthropology". Neither physical nor social anthropology will be superseded but something new will be added. The study of human beings in terms of their biochemical individuality can be said to have started. with Landsteiner's discovery of blood groups, but now, with insight into enzymes, endocrine glands and all the subtle differences in the body-chemistry, the chemist should be able to assemble the kind of information which would explain the 'eachness' of all of us. One thing which Williams shows is that there is no such thing as the 'average man'. Skinner complements this with "The Experimental Analysis of Behaviour".

Not only does the environment determine the conditions under which life exists, but also reciprocally the organisms influence the conditions prevailing in their environment. From that, Redfield proceeds to show how the chemical factors can be influenced biologically. Conversely, Hammond's masterly paper on the statistics of smoking and lung cancer might be said to show how biological factors can be influenced chemically. In the ultramicroscopic environment, we have Beard on "Viruses as a Cause of Cancer", and Turkevich on "The World of Fine Particles" and, to finish up, Zettlemoyer on "Molecular Interactions with the Surfaces of Solids".

Of course, as in any symposium, the quality of presentation varies, but in general it can be said that any intelligent person can have his ignorance of any of the subjects illumined.

Ritchin Calder

\section{THE BRITISH ECONOMY IN TRANSITION}

British Industry

Change and Development in the Twentieth Century. By Dr. J. H. Dunning and C. J. Thomas. Pp. 232. (London: Hutchinson and Co. (Publishers), Ltd., 1961.) 30s. net.

THIS survey of the changes in the British economy since 1914 manages to cover a very broad field in a little more than 200 pages. The topics include industrial structure, ownership and location, energy and power, research and trained man-power, new materials and processes, the State and industry, and international aspects. Drawing on a wide range of sources, the authors have given a clear quantitative picture of developments under each 